\title{
White Knights and Black Knights \\ - Does the Search for Competitive Bids always Benefit the Shareholders of "Target" Companies? -
}

by

\author{
Federico M. Mucciarelli*
}

According to the EC Directive on Takeover Bids, defensive measures should be authorised by the general meeting of the target company. The incumbent board can, nonetheless, search for a competing bid, a so-called "white knight". The rationale underpinning this exception is that competing bids always benefit target's shareholders. In this paper I will tackle this rationale, arguing that even competing bids could generate a pressure to tender on target's shareholders and, therefore, in this case should not be considered as a benefit for them.

I. Defending the besieged castle . . . . . . . . . . . . . . . . . . . 409

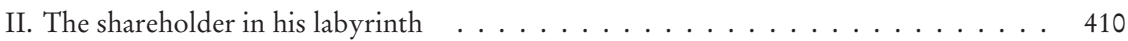

1. The general issue . . . . . . . . . . . . . . . . . . . . 410

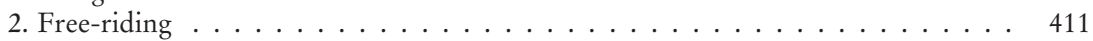

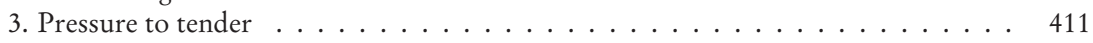

III. Seeking a white knight $\ldots \ldots \ldots \ldots \ldots \ldots \ldots \ldots \ldots \ldots$. . . . . . . . . 415

IV. Black knights . . . . . . . . . . . . . . . . . . . . 416

1. The power of defensive "two-tiered" bids . . . . . . . . . . . . . . . . . . . . . . . . 417

2. "Two-tier" vs. "two-tier" . . . . . . . . . . . . . . . . . . . . . . . . 417

V. Law matters . . . . . . . . . . . . . . . . . . . . . . . . 418

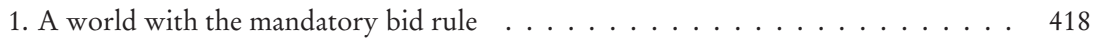

2. Facilitating auctions on target's shares . . . . . . . . . . . . . . 420

3. Drawbacks of the auctions . . . . . . . . . . . . . . . 422

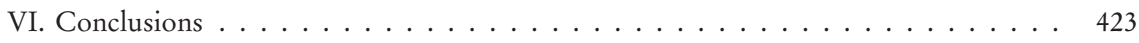

* Assistant professor of business law, Bologna University, Faculty of Economics - federico. mucciarelli@unibo.it

A previous version of this paper has been presented at the European Masters of Law and Economics Program Conference, University of Hamburg School of Law, February $10^{\text {th }}$ 2006. For some helpful comments I would like to thank Luca Enriques, Reiner Kulms, Paolo Santella and Alexander Schall. All errors are mine. 


\section{Defending the besieged castle}

According to the EC Directive, which was approved at the end of 2003 after a lengthy debate ${ }^{1}$, the board of the "target" company should remain passive in front of a takeover-bid ${ }^{2}$. More precisely, Article 9 of the Directive, which follows the model of the City Code on takeovers and mergers of the London Stock Exchange ${ }^{3}$ and of many other European legal systems, provides that "the board of the offeree company shall obtain the prior authorisation of the general meeting of shareholders given for this purpose before taking any action, other than seeking alternative bids, which may result in the frustration of the bid" 4 .

Therefore, defensive measures are not forbidden, on the contrary they are allowed if they are expressly authorised by the shareholders. Put in another way, the general meeting of a listed company is competent to authorise measures which can obstacle the choice of shareholders on whether to tender or not, this means on decisions which could indirectly influence the ownership of the company.

The board of the target company can nevertheless seek a competing bid without being authorised by the general meeting ${ }^{5}$ even if this can frustrate the first takeover-bid. This rule meets a wide acceptance, being applied by most Member States; similarly, Delaware case law, which does not give to the general meeting the competence on defensive measures, requires the target's board to promote an auction when the sale or the break-up of the company becomes unavoidable ${ }^{6}$.

1 Directive 2004/25/EC of the European Parliament and of the Council of $21^{\text {st }}$ April 2004 on takeover bids. OJEU, 30.4.2004, L 142/12, cf. Edwards, “The Directive on Takeover Bids - not worth the paper it's written on?”, ECFR (2004) 416.

2 This "passivity" or "neutrality" rule was nonetheless weakened by an "opt-out" option given to the Member States by the Directive itself: Article 12.

3 City Code on Takeover and Mergers, General principle n. 7: "At no time, after a bona fide offer has been communicated to the board of the offeree company, or after the board of the offeree company has reason to believe that a bona fide offer might be imminent, may any action be taken by the board of the offeree company in relation to the affairs of the company, without the approval of the shareholders in general meeting, which could effectively result in any bona fide offer being frustrated or in the shareholders of the offeree company being denied the opportunity to decide on its merits."

4 Article 9 (2).

5 In the following text I will call this rule for simplicity "white knight exception".

6 Revlon v. MacAndrews and Forbes Holdings, Inc., 506 A.2d 173 (Del. Super 1985), 182; City Capital v. Interco, 551 A.2d, 787 (Del. Ch. $1^{\text {st }}$ November 1988) ; Paramount communications inc. v. Time, 571 A.2d 1140 (Del., 24 $4^{\text {th }}$ July 1989). 
If we admit that during a takeover contest, the board of the target company should pursue only, or at least mainly, shareholder's interests, the "white knight exception" should be praised, because in this way the board puts the shares up for auction, enhancing shareholders wealth.

I will nonetheless argue that this exception could be unfair for shareholders' interests. After the launch of a takeover bid, shareholders face collective action problems, which compel them to tender even though this is not in their collective best interest (so-called pressure to tender). Competing bids could be coercive as well, forcing shareholders to tender even if the bid launched at first is more convenient; hence, seeking a coercive competing takeover-bid does not fit the rationale underpinning the "white knight exception”.

The work will proceed as follows. In the second section I will briefly summarise the issue of collective action problems related to takeover bids. In the third section I will describe the arguments supporting the case for seeking a competitive bid by the incumbent board without being authorised by the general meeting. In the forth section I will discuss some examples of coercive competing takeover bids; I will argue that if the competitive bid raises collective action problems this is neither efficient nor coherent with the ratio legis of the Directive, admitting the incumbent board to seek a white knight without being authorised by the general meeting.

\section{The sharebolder in his labyrinth}

\section{The general issue}

Any decision of target shareholders on the merit of an offer is affected by collective action problems ${ }^{7}$, as it happens in every case when more persons should take individually a decision on a certain problem without having the ability to coordinate among themselves and the utility of each person depends on the choices made by the others. In case of takeover-bids shareholders should choose whether to sell their shares to the offeror or to hold

7 The following arguments are based on the assumption that shareholders behave rationally in order to maximise their utility. I assume that a person acts rationally if she acts in the best way in order to reach a specific goal and her preferences are transitive.

Preferences are transitive in this case: if some good " $A$ " is preferred to a good " $B$ ", and this latter good " $\mathrm{B}$ " is preferred by the same person to a good " $\mathrm{C}$ ", then should follow that also " $\mathrm{A}$ " is preferred to " $\mathrm{C}$ ". (Putting it in a formal way, we write it as follow: $\mathrm{A}>\mathrm{B} \wedge \mathrm{B}>\mathrm{C} \rightarrow \mathrm{A}>\mathrm{C}$.) See Ulen, "Rational choice theory in law and economics", in Encyclopaedia of Law and Economics, http://encyclo.find.law.com, 790. 
them. Thus, after a takeover bid is launched, shareholders compare the price of the bid with the expected value of minority shares if the bid succeeds. But a shareholder can not know what other fellow shareholders are going to decide on the merit of the offer, and coordination among them is too costly and almost impossible. We can distinguish two cases indeed.

\section{Free-riding}

If the expected value of minority shares under the new controlling shareholders is considered by the majority of shareholders as higher than the value under the incumbent shareholders, then it is rational for shareholders to hold their shares, hoping that other shareholders will sell them.

The success of the bid is not impeded by the fact that a minority of shareholders, or even only one of them, did not sell their shares ${ }^{8}$. If every shareholder behaves in this way, however, none of them will tender, hoping that fellow shareholders will sell their shares. If this happens, a value-increasing takeover-bid is going to fail ${ }^{9}$.

\section{Pressure to tender}

If the expected value of minority shares after a successful bid is presumed to be lower than the price offered, shareholders are forced to sell, although under an ex post point of view this is not the best choice for them (so-called pressure to tender); in this case a value-decreasing takeover bid is going to succeed $^{10}$.

Indeed, shareholders do not know whether other shareholders will tender their shares or not and they cannot coordinate their behaviour among each other. If the bid succeeds shareholders risk to lose the price of the offer, bearing only under-priced minority shares; hence, the decision to tender is

8 Goshen, “Voting (insincerely) in Corporate Law”, 2 Theoretical Inq. L. (2001) 815.

9 Grossman - Hart, "Takeover bids, the free-rider problem and the theory of the corporation”, 11 Bell Journal of Economics (1980) 42.

10 Bebchuk, "Toward undistorted choice and equal treatment in corporate takeovers", 98 Harv. L. Rev. (1985) 1693 and "The pressure to tender: an analysis and proposed remedy”, 12 Delaware Journal Corp. Law (1987) 926. On a side note, it is woth mentioning that the German companies' group law provisions, in particluar on dominion agreements, that have often been criticised as overcomplicated, mitigate the value decreasing problem and compensate the loss of the minority shareholder, $\mathbb{S} 304,305$ Aktiengesetz $[A k t G]$. On group law, cf. further the article by Girgado in this issue. 
dominant. Of course, the choice made by shareholders depends on how the bid is likely to be successful: the more shareholders hold for likely that the bid succeeds, the more they are coerced to sell their shares.

\section{a) Partial and "two-tiered" bids}

Law and economics theory suggests that partial and "two-tier" offers place on shareholders the biggest pressure to tender.

- Partial bids. After the bid has succeeded, tendering shareholders hold only an average value among the price offered and the value of the minority shares under the new management ${ }^{11}$. Therefore, shareholders would be better-off if they could coordinate themselves not selling their shares. Since any sort of coordination is too expensive, the optimal strategy for shareholders, under an ex ante point of view, is to tender ${ }^{12}$.

- "Two-tiered" bids. The offeror launches a first partial "front-end" offer at a high price, promising to launch a second "back-end" bid for the rest of the shares at a lower price. For shareholders this situation is similar to the one faced when a partial offer is launched, the "back-end" price being comparable with the expected value of the minority share if the partial offer succeeds ${ }^{13}$. Shareholders will rationally tender, fearing to gain only the lower "back-end" price.

The difference between the "front-end" and the "back-end" price is of great relevance on shareholder's choices: the greater this difference is, the greater is the potential loss for non-tendering shareholders and the more shareholders are forced to tender ${ }^{14}$.

11 The value depends on the amount of shares which the offeror is keen to purchase through the bid, and the number of tendered shares.

12 If shareholders sell, they lose the difference between the offered price and the lower value of minority share they will hold after the bid succeeds.

13 Brudney - Chirelstein, "Fair shares in corporate mergers and takeovers", 88 Harvard Law Journ. (1974) 297; Subramanian, “A new takeover defense mechanism: using an equal treatment agreement as an alternative to the poison pill”, 23 Del. Journ. Corp. Law. (1998) 402; Mülbert - Birke, "In defense of passivity - on the proper role of a target's management in response to a hostile tender offer”, 1 EBOR (2000) 468.

See also Delaware Supreme Court Paramount (n. 6) at HN7 "In a two-tier, highly coercive tender offer, the threat is obvious: shareholders may be compelled to tender to avoid being treated adversely in the second stage of the transaction".

14 Bradley - Kim, "The evolution of the tender offer as a takeover device: an analysis of ownership structure, the free rider problem, and the prisoner's dilemma”, unpublished, (1984) 295; Oesterle, "The negotiation model of tender offer defences and the Delaware Supreme Court”, 72 Cornell L. Rev. (1986), 127. 
"Two-tier" and partial bids could allocate resources in an inefficient way. We can make the following example in order to understand this point. Let us assume that a potential target has 10 outstanding shares, each one worth $50 €$; this means that the market value of the firm is $500 €$. Let us now assume that an offeror launches a "two-tier" bid shaped as follows: a first "front-end" bid for 5 shares at $60 €$, and a second, "back-end" bid for the remaining 5 shares at $20 €$ each. The offer is conditioned upon the tendering of 5 shares. Rational shareholders, fearing to get only the low "back-end" price, will tender and the bid will therefore succeed. If the value of the firm under the new majority is less then $500 €$, then the bid should be considered as value-decreasing, because the offeror is keen to pay only $400 €$ for a firm which was worth $500 €$, without diminishing the value of the firm itself.

\section{b) The mandatory bid rule}

In order to limit partial and "two-tier" bids, the Directive introduces at a EU level the "mandatory bid rule", providing that any persons, who purchases the control of a listed company ${ }^{15}$, should launch a takeover bid on $100 \%$ of shares carrying voting right at the higher price paid for shares over a period between 6 and 12 months before the bid.

Therefore, partial bids are not forbidden at EU level, they are rather more difficult to be used for taking over a company, as a partial bid should be always followed by a $100 \%$ bid for the outstanding shares at the same price.

In a world with the mandatory bid rule in place the game is similar to the one described for "two-tier" offers, where the mandatory bid following a partial bid can be compared with the "back-end" bid. Therefore, the pressure to tender placed on shareholders depends on the price of the mandatory bid: if this is lower than the price of the partial bid, shareholders could face a pressure to tender similar to the one placed by "two-tier" offers.

Applying the result reached before on "two-tier" bids, we can say that the greater is the difference between the price paid for crossing the relevant threshold and the price of the mandatory bid, the greater is the pressure on shareholder to tender to a partial bid. But as we have seen, according to the EC Directive, mandatory bids should be launched at the higher price paid by the offeror for crossing the threshold; hence the Directive eliminates the most relevant collective action problems placed by partial bids.

15 More precisely: a threshold which let presume having the control, according to the law of the Member State where the target company has her registered office. Article 4. 
Member States can, nonetheless, give their supervisory authority the power to derogate to the higher price rule, allowing launching a mandatory bid at a lower price, in extraordinary cases where the higher price paid for crossing the relevant threshold is unsound ${ }^{16}$. The Directive does not harmonise this issue, which is left to the regulation of each Member State. We could, therefore, expect having 25 different laws on the price of the mandatory bid ${ }^{17}$.

\section{c) $100 \%$ all-cash takeover-bids}

But even $100 \%$ all-cash takeover-bids can place a pressure to tender on shareholders.

As we have seen before, in case of a value-decreasing bid, shareholders would be better-off if they could collectively decide not to tender. In this case a value-decreasing bid would be defeated ${ }^{18}$. Shareholders cannot coordinate themselves and they do not know whether fellow shareholder will tender or not tender. Shareholders compare the risk of holding minority undervalued shares, in case of success of the bid, with the price of the offer, hence the optimal ex ante strategy is to tender.

If the offeror has a duty to purchase all non-tendered shares at the same price of the bid or to extend the offer period after the bid succeeds ${ }^{19}$, we could argue that the bid does not place on shareholders any pressure to tender. In these cases non tendering shareholders do not risk to hold minority undervalued shares after the bid succeeds, therefore they are free to reject the offer if they do not hold it as convenient ${ }^{20}$.

16 Article 5 (4).

17 Enriques, "The mandatory bid rule in the takeover directive: harmonization without foundation?”, ECFR (2004) 446.

18 Bebchuk, "Efficient and inefficient sales of control”, Quarterly Journal of Economics (1994), 957 et seq.

19 Such a duty could rest either on a clause of the bid itself, or on the law, as it is the case in some EU Member States. See: London City Code on Takeovers and Mergers, Rule 31.4; German WpÜG, $\mathbb{S} 16$ (2); Austrian ÜbG, $\mathbb{} 19$ (3); Swiss ÜV-ÖK, Article 27 (2), providing that succeeding bids should be left open for two weeks after their end. Of course, in this way takeover bids are more expensive and therefore rather infrequent.

20 Gilson - Kraakman, "Delaware's intermediate standard for defensive tactics: Is there substance to proportionality review?”, 44 Bus. Lawyer (1988) 254. 


\section{Seeking a white knight}

The general meeting is competent on decisions which could indirectly influence the composition of share ownership ${ }^{21}$; the board can nevertheless seek a competing bid without the need to be authorised by shareholders.

The goal of this "white knight exception" seems clear. An auction on target shares pursues shareholders' interests; hence it is not necessary to attribute to the competence of the general meeting the decision to seek for a potential bidder and to transfer to him any useful information.

In order to understand the rationale lying behind of the "white knight exception" we can imagine a world where there is a "passivity rule" in place, but the wording of the law does not provide for any exception to the competence of the general meeting. This was the case, for instance, under German law before the Wertpapiererwerbs- und Übernahmegesetz (Wp $\ddot{U} G$ ) on takeover regulation ${ }^{22}$, and under Italian law even now ${ }^{23}$. We should nonetheless ask ourselves whether seeking competing bids does really need being authorised by the general meeting, as it were a common defensive measure, or not. The answer should be for the negative if we assume that the board has a general duty to maximise what shareholders earn selling their shares and that the "passivity rule" is a logic consequence of this general duty ${ }^{24}$; hence, we can

21 See Merkt, "Verhaltenspflichten des Vorstands der Zielgesellschaft bei feindlichen Übernahmen”, 165 ZHR (2001) 249, which was related to a general "passivity duty" placed to the board in front of a takeover, but in a time where neither the EC nor the national (i.e. German) law provided for a competence of the general meeting on defensive measures.

22 Enacted in 20.12.2001. The neutrality rule is stated in $₫ 33 \mathrm{WpÜG.} \mathrm{Under} \mathrm{German} \mathrm{law}$ before 2002, only a non binding acquisition codex provided for a general passivity rule; most legal scholars held, nonetheless, that the board should stay passive in front of a takeover attempt, but could seek for a competing bid: Mertens, in Kölner Kommentar zum Aktiengesetz ( $2^{\text {nd }}$ edn. 1996) \ 76 [26]; Hopt, "Aktionärskreis und Vorstandsneutralität", ZGR (1993) 547; Id., "Verhaltenspflichten des Vorstands der Zielgesellschaft bei feindlichen Übernahmen”, in FS Lutter (2000) 1383; Berrar - Schnorbus, "Rückerwerb eigener Aktien und Übernahmerecht", ZGR (2003) 101 et seq.

23 Testo Unico della finanza $(T U F), 1998$, Article 104. The Italian authority on capital markets (CONSOB) addressed this issue in the case of the takeover-bid on Telecom's shares, stressing that even if the law spends formally no word relating the seeking of a white knight, this does not need being authorised by the general meeting; see DAL/99039392, 18.5.1999 on www.consob.it.

24 Hopt (n. 22) 558; Vella, "La nuova passivity rule nella disciplina italiana delle offerte pubbliche d'acquisto: alla ricerca di un difficile equilibrio", Banca Impresa Società (2000) 169; Berrar - Schnorbus, (n.. 22) 101; Hirte, "Verteidigung gegen Übernahmeangebote und Rechtschutz des Aktionärs gegen die Verteidigung”, ZGR (2002) 639; Id., 
argue that seeking competing takeover-bids is not covered by the rationale underpinning the general passivity rule and that the board can put the shares up for auction ${ }^{25}$.

If we make a step further on this line, we can infer that the main policy goal underpinning the "white knight exception" is to maximise the revenue for shareholders selling their shares, not necessarily the maximisation of social wealth or the efficiency; we could nonetheless consider revenue maximisation of target's shareholders as a proxy for the efficient allocation of share's ownership rights, as in this way the firm is sold to the bidder who is keen to offer the higher price $^{26}$.

\section{Black knights}

In the former section I have shown the argument supporting the "white knight exception". In the next section I will point out that some defensive takeover-bids could be coercive, or more coercive than the first hostile bid. I will make firstly two examples which do not consider any specific set of rules.

Kölner Kommentar zum Wp ÜG (2003) $\mathbb{S} 33$ [75], [96]; Merkt (n. 21) 249. Cf. on the question in whose interests the company is to be run Schall - Miles - Goulding, "Promoting an Inclusive Approach on the Part of Directors: The UK and German Positions", JCLS (2006) 299.

25 See the authors cited in the previous footnote, and adde: Bebchuk, "The case for facilitating competing tender offers", 95 Harv. Law Rev. (1982) 1028; Id., "The case for facilitating competing tender offers: a reply and extension”, 35 Stanford Law Rev. (1982) 23; Gilson, "Seeking competitive bids versus pure passivity in tender offer defense”, 35 Stanford Law Rev. (1982), 24 et seq.

26 See for instance the Bebchuk's model for efficiency in corporate transactions. Assume that: $\mathrm{Wn}=\mathrm{Mn}+\mathrm{Bn}$ (where: $\mathrm{Wv}=$ total value of the firm under incumbent management; $\mathrm{Mv}=$ stock capitalisation under incumbent management; $\mathrm{Bv}=$ private benefits of control under incumbent management), and that: $\mathrm{Wn}_{n}=\mathrm{Mn}+\mathrm{Bn}$ (where: $\mathrm{W}_{\mathrm{N}}=$ firm value after bid succeeds; $\mathrm{MN}_{\mathrm{N}}=$ stock capitalisation if bid succeeds; $\mathrm{BN}_{\mathrm{N}}=$ private benefits of control of the new management), then a transfer of control is efficient if: $\mathrm{Wv}=\mathrm{Mv}+$ $\mathrm{Bv} \leq \mathrm{WN}_{\mathrm{N}}=\mathrm{MN}_{\mathrm{N}}+\mathrm{BN}$.

This model relies upon some values, which could be rebutted; for instance, we could: a) hold that the market value is not significant for establishing the "true" or "right" value of a firm; b) consider the private benefits of control as always negative on firm's value (on the contrary, in the Bebchuk's model the higher is $\mathrm{B}$, the higher is also W); c) consider the interests of other stakeholders, as employee or creditor, as relevant for assessing the efficiency of a transaction; see COFFEE JR, "Regulating the market for corporate control: Analitical assessment of the tender offer's role in corporate governance”, 84 Col. Law. Rev. (1984) 1145 et seq. 


\section{The power of "two-tiered" defensive bids}

We can begin depicting the following example, where a defensive "two-tiered" bid is launched against a first $100 \%$ all-cash hostile takeover-bid.

The listed company A has 10 outstanding shares. B launches a $100 \%$ cash takeover bid at a price $\mathrm{P}=10 €$, promising to extend the offer period at the same price after the bid succeeds. $B$ is, therefore, keen to pay $100 €$ for the company.

The incumbent board reaches an agreement with $\mathrm{C}$, according to which the latter will launch a competing bid on A's shares. C launches a "two-tier" bid, where the "front-end" bid is launched for 5 shares at $12 €$, i.e. at a price which is higher than the price of the first bid, and the "back-end" price is much lower $(6 €)$. The blended price of this competing takeover bid is therefore $9 €$, which is lower than the price offered by the first offeror $\mathrm{B}$.

In this case, target shareholders face a heavy pressure to tender. If all shareholders would tender to the first offer, they would earn the price $\mathrm{P}(10 €)$, which is higher than the blended price of the second offer $(9 €)$; therefore, shareholders would be better-off if they could cooperate deciding not to tender. But under an ex ante point of view, individual shareholders cannot be sure on what other shareholders will decide on the merit of the offer and cannot coordinate cheaply; hence, under the viewpoint of a shareholder facing this dilemma, two alternatives are possible: (a) if the second offer fails and the first offer succeeds, shareholders can tender to the first offer even if they tendered previously to the competing "two-tiered" bid; (b) on the contrary, if the shareholder would tender to the first bid, but the second one succeeds, shareholder gains only the lower "back-end" price of the second bid $(6 € \text { in the example })^{27}$. Hence, a rational shareholder should tender to the competing "two-tier" bid.

\section{2. "Trwo-tier" vs. "two-tier"}

What happens if the first hostile takeover-bid is "two-tiered"? Assume that the bidder B launches a "two-tier" takeover bid on the 10 outstanding shares of the company A shaped as follows: the "front-end" bid is launched for 5 shares at $56 €$ a share and the "back-end" bid for the rest of the shares will be launched at $50 €$. The blended price is therefore $53 €$.

27 See SEC, “The economics of partial and two-tier tender offers", Federal Securities Law Reporter, 1984, n. 21, 926 (an empirical research of SEC on the years $1981-1983$ did not confirms this conclusion). 
After this bid, the board of the target company seeks a third person, C, for launching a competing tender offer. The competing bid launched by $\mathrm{C}$ is "two-tiered" as the first bid, but is shaped in a different way: the "front-end" bid is launched for 5 shares at $60 €$, which is a higher price than the "front-end" price of the first bid; the "back-end" price is $40 €$, which is far lower than the "back-end" price of the first bid. The blended price of the second takeover-bid is therefore $50 €$.

Although the blended price of the competing offer is lower than the blended price of the first offer, shareholders will rationally choose to tender to the competing offer. The reason is that the difference between the "front-end" price and the "back-end" price of the first offer is lower than the same difference in the second offer; hence the latter is more coercive than the former ${ }^{28}$. If the competing bid succeeds, shareholders who tendered to the first bid risk to gain only the low "back-end" price of the competing bid (40€ in our example); hence, the dominant strategy is to tender to the competing bid, even if the blended price of the first bid is higher than the blended price of the latter, and under an ex post point of view this is not the best possible choice for shareholders ${ }^{29}$.

\section{Law matters}

\section{A world with the mandatory bid rule}

As we have seen in the second section, the EC Directive provides for a general mandatory bid rule, according to which if a person purchases the control of a company, she should then launch an offer for all the outstanding shares. In this case, the payout of the competing game depends on the price which should be paid for the mandatory bid.

\section{a) Mandatory bid at a price lower then the price paid for crossing the control threshold}

The law could allow launching the mandatory bid at a price lower than the price paid by the bidder for crossing the control threshold ${ }^{30}$. Under a game

28 Oesterle (n. 14) at p. 129, n. 49.

29 Bradley - Kim, "The evolution of the tender offer as a takeover devise: an analysis of ownership structure, the free rider problem and the prisoner's dilemma" unpublished (1984) 293.

30 At the moment this is still the case in England (Rule 9.4 Takeover Code) and Italy (Article 106 (2) TUF). 
theory analysis, this case is similar to the ones depicted in Section IV.2, where a "two-tiered" hostile bid faces a defensive bid which is "two-tiered" as well.

Indeed, the battle can be depicted as follows. The hostile bid launched by $\mathrm{B}$ on A's shares is followed by a competing partial bid; both bids are conditioned upon the fact that the majority of shareholders will tender. Whatever bid will win, a mandatory bid at a lower price should be launched. Both partial bids, therefore, are comparable with "front-end" bids, and the following mandatory bids are "back-end" bids at a lower price.

The payout of this game depends on the formula used by the law for calculating the price of the mandatory bid. We should remind what was stressed above: the higher is the difference between "front-end" price and "back-end" price, the more is a bid coercive; hence, the takeover-bid having the higher spread between "front-end" and "back-end" price should win. Therefore, if the difference between the prices of the hostile partial bid and its following mandatory bid is lower than the spread for the competing bid, then the latter is more coercive and should win.

\section{b) Mandatory bid at a the same price paid for gaining the control}

On the contrary, if the price of the mandatory bid is equal to the highest price paid for crossing the control-threshold, as under the general rule of the EC Directive ${ }^{31}$, the payout of the competing situations described before is different.

Assume that B launches a partial takeover bid for 6 shares at $12 €$. The bid is conditioned upon the fact that at least 6 shares are tendered. If this partial bid succeeds it will be followed by a mandatory bid at the same price ${ }^{32}$; therefore, the total price paid by B for the company A will be $120 €$.

After the launch of the first partial bid, the board seeks a competing $100 \%$ all-cash takeover bid at $11 €$ per share; the total price which the competitor is keen to pay is therefore $110 €$.

We should distinguish two cases.

31 Article 5 (1). The Directive allows Member States to provide for exceptions to the general rule. The mandatory bid rule at the highest price paid by the bidder was followed even before the Directive in Belgium (Article 14 Arrete royal relatif aux offres publiques d'acquisition et aux modifications du contrôle des sociétés, 1989), Germany ( $\$ \int 3$ et seq. Wp ÜG-Angebotsverordnung) and Hungary (\$ 72 (1) (a) Act CXX/2001 on capital market); Austrian law changed relating to this issue in order to comply with the Directive: see the new $\mathbb{2} 26$ Übernabmegesetz, as changed by the law 75/2006.

32 It could make sense to launch a partial bid, instead of a unique $100 \%$ cash bid, because in this way the bidder could finance easily the takeover in two steps; Enriques (n. 17) 446. 
1) If the offer period of the competing bid does not need to be extended after the bid succeeds, then if the competing bid succeeds shareholders who tendered to the first bid, or held their shares, risk holding minority shares, which they cannot tender to the competing bid anymore. If we assume that shareholders are risk-adverse or risk-neutral, the dominant strategy for them, therefore, is to tender to the second bid, even if its total price is lower than the price of the first bid.

Putting it in a more general way, in a world with a mandatory bid rule at the same price paid for crossing the relevant threshold, a $100 \%$ all-cash takeover bid is more coercive then a partial bid, if the offer period of the competing bid does not need to be extended after the bid succeeds ${ }^{33}$.

Nonetheless, the first bidder can win the takeover contest, if he only extends his bid to all outstanding shares at $12 €$, providing that the law allows the bidder to increase his offer, as will be stressed in the next pages.

2) If the offer period of the competing bid should be extended after the bid succeeds, the payout of the game is different. If the first hostile bid fails, tendering shareholders can nonetheless sell their shares to the winning competing offeror. Shareholders, therefore, can choose either bid, according to the value attached to him; the first partial bid should prevail because the total price paid for gaining the control is higher than the price offered by the competing bidder. If this is the case, shareholders do not suffer any pressure to tender.

We should not forget that the mandatory bid rule at the highest price paid for crossing the relevant threshold faces a significant drawback under the viewpoint of social welfare. The rule is aimed at enhancing target's shareholders' wealth, but makes takeover-bids more expensive and, therefore, rare ${ }^{34}$. Under an efficiency rule, we should compare the advantages in terms of efficiency produced by the mandatory bid rule and the disadvantages of having fewer takeover-bids on the market.

\section{Facilitating auctions on target's shares}

Law can mitigate the pressure to tender caused by competing tender offers, allowing the first bidder to increase the price offered or to extend the offer to all outstanding shares. Doing this, the first bidder can win the battle even if the competing offer is coercive.

33 Enriques (n. 17) 446.

34 Among other see Baum, "Funktionale Elemente und Komplementaritäten des britischen Übernahmerechts”, RIW (2003) 421 et seq.; Burkart - Panunzi, "Mandatory bids, squeeze-out, sell-out and the dynamics of the tender offer process", ECGI Working paper series in law, n. 10, 2003, http://www.com/link/ECGI-Law.html. 
This is realistic only if the law authorises shareholders who already tendered to the other offer to withdraw their acceptance and sell their shares to the first bidder, if the latter increased the price or extended the offer to a higher number of shares ${ }^{35}$.

Another legal device is necessary in order to treat the first bidder equal to its competitor: the incumbent board should have a duty to provide to the hostile bidder the same information he granted to the white knight. For instance, if the competing bidder made a "due diligence" of the target company in order to establish the right price, the same should be allowed to the first bidder, which could eventually increase the offered price relying upon this new information ${ }^{36}$. Despite the fact that this equal treatment of competing bidders is not expressly written in the wording of the directive, this rule stems from the rationale of the "white knight exception", which is to maximise shareholder's revenue through an auction on their shares, not to prefer a bidder over another ${ }^{37}$.

If the law provides for these rules in order to place the hostile bidder and the competing bidder at the same footing, the former can increase the price offered and can win the battle.

Let us come back to the examples made before. In the first example, the first offeror (B) can win the battle against the coercive competing bid if he increases the offered price reaching the "front-end" price of the competing bid, that is, according to my example, $12 €$ instead of $10 €$. In the second example, $\mathrm{B}$ can win the battle extending the offer to all outstanding shares and increasing the price till the "front-end" price of the competing bid. Nonetheless, we should pay attention to the fact that the choice to extend the bid or to increase the price is financially not neutral for the first bidder, as he will probably suffer the cost of paying interests for borrowing the sum he needs;

35 As is the case according to the takeover laws of most Member States: Austria ( $\mathbb{1 7}$ ÜbG); Germany ( $\$ \mathbb{S} 22$ WpÜG); Italy (Art. 40 (3) CONSOB Regulation); partially different is the regulation of the English City Code: shareholders can withdraw their acceptance only if the offer was not yet declared as unconditional as to acceptance (Rule 34 City Code).

36 Fleischer "Konkurrenzangebote und due diligence", ZIP (2002) 653; Hopt, "Übernahmen, Geheimhaltung und Interessenkonflikte. Probleme für Vorstände Aufsichtsräte und Banken” ZGR (2002) 358.

37 Hirte, "Verteidigung gegen Übernahmeangebote und Rechtschutz des Aktionärs gegen die Verteidigung“, ZGR (2002) 623, 640. See Rule 20.2 of the English takeover code "Any information, including particulars of shareholders, given to one offeror or potential offeror must, on request, be given equally and promptly to another offeror or bona fide potential offeror, even if that other offeror is less welcomed." 
we can expect that a certain, although unpredictable, amount of advantageous bids would be defeated by coercive defensive bids, if the borrowing costs for enhancing the offer are unsustainable for the first bidder.

\section{Drawbacks of the auctions}

A regulation which allows the incumbent board to seek competing bids has a significant drawback in terms of social welfare and efficiency.

It should be stressed, indeed, that information is a valuable good which is not freely available and, therefore, should be produced by any potential bidder. The first offeror has probably borne high expenses in order to discover and to evaluate the possible target; investments made by the hostile bidder for discovering and evaluating a potential raider can be upheld only if the takeover-bid succeeds. White knights, on the contrary, do not suffer any cost for discovering and assess the target, being all information provided to them by the incumbent board; hence, the white knight does not need to discount these kind of costs and can offer a higher price.

This outcome does not change even if the board has a duty to provide the hostile bidder with the same information given to the white knight, as this duty does not help the first bidder to gain information for discovering and assessing a potential target.

We can make following simplified example. Assume that $N$ is the cost suffered by the first bidder (B) for discovering the target $A$; the expected value of the target after the bid succeeds is $V^{1}$. The costs paid by B for the needed information should be rescued after the bid succeeds, hence the price $(P)$ offered by B will discount these costs $\left(P=V^{1}-N\right)$. The incumbent board seeks a competing bid, transferring to him the information he needs for assessing the target. Assume that the expected value of the target if the competing bid succeeds $\left(V^{2}\right)$ is the same as if the hostile bid succeeds (that is to say $V^{1}=V^{2}$ ). In other words, this is a so-called "common value auction", where all competing bidders attach the same value to the target; this is the case if takeover-bids are motivated by mismanagement of the incumbent board, not by synergy gains, which would be different for each bidder ${ }^{38}$. The competing bidder did not need to invest money for discovering and assessing the target, hence the price he offers does not need to discount this kind of costs and can be higher than the price offered by the hostile bidder $\left(P^{2}=V^{1}=V^{2}>P\right)$.

38 Cramton - Schwartz "Using auction theory to inform takeover legislation" 7 JLEO (1991) 29. 
A regulation encouraging auctions on target's shares and allowing the board to seek a white knight, therefore, would discourage potential bidders to invest money for discovering targets and in this way risks to reduce the total amount of takeover-bids on the market ${ }^{39}$.

\section{Conclusions}

The purpose of the present work was to address the question whether seeking a competing bid should be allowed to the incumbent board without any limitation and without being approved by the general meeting. Despite a common view arguing for the opposite, allowing the incumbent board to seek for a competing bid without any restriction seems to be problematic. We focussed our attention on two drawbacks of the "white knight exception".

On the one hand, competing bids could place a pressure to tender on targeted shareholders, unless the applicable law provides for legal devices aimed at limiting collective action problems. This drawback is relevant under the policy goal to maximise shareholders' revenue in a specific takeover contest; if this happens, the shares are not sold to the offeror who is keen to pay more for them and we should consider this as an inefficient allocation of target's ownership.

On the other hand, the "white knight exception" could represent a disincentive for potential bidders to make investment in order to search and to asses a target. This second drawback is significant under the policy goal to maximise efficiency and social gain, but is not significant if the law is aimed only at maximising shareholders' revenue in a specific takeover contest.

The EC Directive seems to endorse only the goal to maximise shareholders' revenue; if we accept this, then the "white-knight exception" is coherent with the policy goal of the Directive only if the competing bid is not coercive. The reason is easy to be explained: if the competing bid sought by the board is coercive, this is not in the best interest of shareholders and the rationale underpinning the "white knight exception" fails ${ }^{40}$.

39 See Easterbrook - Fishel "The proper role of a target's management in responding to a tender offer" 94 HLR (1981) 1161; Schwartz "Search theory and the tender offer auction” 2 JLEO (1986) 229; regarding the “white knight exception” see: Sàez La cave "Una aproximacion al derecho de las opas competidoras (a proposito de una reforma reciente)" Rev. Derecho Bancario y Bursatil (2003) 33.

40 This is admitted also by Delaware case law; see Delaware Supreme Court Paramount (n. 6) HN11 "Even in light of a valid threat, management actions that are coercive in nature or force upon shareholders a management-sponsored alternative to a hostile offer may be struck down as unreasonable and nonproportionate responses". 
If a competing bid is coercive depends also on the applicable law, which can mitigate or eliminate the "pressure to tender" through a mandatory bid rule or allowing the first bidder to increase the offered price.

The EC Directive partially harmonises only the mandatory bid rule. According to the general rule, the mandatory-bid should be launched at the highest price paid for crossing the control threshold; this limits the pressure to tender placed by competing bids, but makes takeover attempts more expensive. Member States can relax the price rule, allowing mandatory bids at lower prices, but in doing this they could generate the preconditions of coercive competing bids, according to the method used for establishing the price of the mandatory bid.

As we have seen, the law can hinder or mitigate the pressure to tender caused by a competing bid, levelling the playing field among competing offers. Most regulation of Member States provides for rules which place the first offeror at the same footing with its competitor ${ }^{41}$; hence coercive competing bids should be rare throughout the European Union. But we should also stress that the EC directive does not harmonise rules on competing bids neither; hence the applicable takeover law theoretically might still allow coercive defensive bids.

We should consider also that the EC Directive is to be applied only if the target company is both incorporated in a Member State and listed in a regulated market of a Member State ${ }^{42}$. In all other cases, Member States are free to hold their own conflict rules also for takeover law ${ }^{43}$, which usually refer to the law of the country where the company is listed, being the regulation of competing takeover-bids part of the market regulation, not of company $\mathrm{law}^{44}$.

41 The bidder can increase its offer. Shareholders who already tendered to the other bid can withdraw their acceptance.

42 Article 1 (1).

43 Siems, "The rules on conflict of laws in the European takeover directive", ECFR (2004) 461; von Hein, "Zur Kodifikation des europäischen Übernahmekollisionsrecht” ZGR (2005) 528 et seq.; Garcimartìn Alférez "Ofertas publicas de adquisicion de acciones: problemas de ley aplicable”, Rev. Soc. (2006) 127.

44 I follow the traditional distinction between company law and capital market law, the former being the law of the internal organisation of the corporation, and the latter the (private or public) law of the exchange of shares; this issue can not be deepened in this work; see Kübler, "Gesellschaftsrecht versus Kapitalmarktrecht - zwei Ansätze?”, SZW (1995) 223 et seq.; Costi, "Il governo delle società quotate: tra ordinamento dei mercati e diritto delle società", Dir. Comm. Int. (1998) 65 et seq.; von Hein "Grundfragen der europäischen Übernahmekollisionsrecht” AG (2001) 219 et seq. 
Let us assume that a company based in a Member State and listed only in a non-EU market becomes the target of a takeover-bid ${ }^{45}$. The incumbent board seeks for a white knight launching a competing-bid. To the competing bid should be applied takeover law of the country where the target company is listed; let us imagine that the applicable law provides neither for a "mandatory bid rule", nor for any rule aimed at limiting the coercive effect of partial and "two-tiered" bids. In this case, the incumbent board would be able to seek for a coercive competing bid that would force shareholders to tender even if this is not in their interests under an ex post viewpoint.

Under these circumstances, therefore, coercive defensive bids are still possible. Although the wording of the Directive does not distinguish coercive competing bids from non coercive ones, courts could follow a teleological application of Article 9 (1) and apply the "white knight exception" only to the latter. Indeed, the rationale of the "white knight exception" is to allow the incumbent board to enhance shareholders' wealth, putting their shares up for auction; seeking a coercive bid does not fit the ratio of the "white knight exception", and the exception has no reason to be applied.

45 I assume for simplicity that the applicable law provides for the passivity rule and the "white knight exception" even if the company is listed in a non-EU market. 